\title{
Biostratigraphy and depositional environment of the sediments in Borno Basin, North Eastern Nigeria
}

\author{
Adebanji Kayode Adegoke \\ Department of Geology, Faculty of Science, Ekiti State University, P.M.B. 5363, Ado-Ekiti, Nigeria. \\ kayodeadebanji@yahoo.com
}

\begin{abstract}
A biostratigraphic study was carried out on 83 drill cutting samples retrieved from Kemar-1 well, Borno Basin, northeastern Nigeria. They were subjected to palynological and foraminiferal analyses to determine their biozonation, age and depositional paleoenvironments. The studied intervals ranged between 600 and 1745 metres and were sampled at 30- and 20-metre intervals for the palynological and foraminiferal analyses respectively. Lithologically, the drill cutting samples are made up mainly of predominantly grey to dark grey shale, sandy mudstone and silty mudstone. An igneous rock with argillaceous sandstone and argillaceous siltstone intercalations was also observed. Three major palynological assemblage zones were recognised in the study area. They are Cretacaeiporites scabratus/mulleri Assemblage Zone, which correlates with the basal sequence, Droseridites senonicus Assemblage Zone, and Proteacidites dehaani/Dinogymnium euclaense Assemblage Zone of the well section's upper part. Also, two foraminiferal biosequences were established for the studied interval. The environment of deposition of the well was generally shallow. It ranges from Coastal Deltaic in the upper part through Fluviomarine to Shallow Inner Neritic in the lower part of the Fika 'Shale' Formation. The age of the fossiliferous interval of the studied section of the well ranges from Early Turonian at the base to Early Campanian at the top. Three unconformities were observed and mapped within the studied section of the well at $790 \mathrm{~m}, 1300 \mathrm{~m}$ and $1700 \mathrm{~m}$. The unconformities were marked by noticeable faunal discontinuities, associated with reduction in paleowater depth and abrupt shift in the environment of deposition. Biostratigraphy is a valuable tool in oil and gas exploration when it is integrated with other geological and geophysical data sets, such as outcrops, seismic lines or well logs. This paper constitutes a significant contribution to the understanding of the biostratigraphy of Borno Basin, which is currently the focus of intensive hydrocarbon exploration activities.
\end{abstract}

Keywords: Biostratigraphy, Depositional environments, Bornu Basin, Fika "Shale" Formation, Turonian

Introduction

Borno Basin is one of Nigeria's frontier inland sedimentary basins which the Government currently targets for the expansion of the country's hydrocarbon exploration and production base and augmentation of proven reserves asset. It is the Nigerian part of the much larger Chad Basin which covers several African countries. To date, no commercial petroleum deposits have been discovered in the Borno Basin unlike in the Chad Basin parts in the neighbouring countries [Chad, Niger, and Sudan] with similar structural settings. This has prompted intensive studies in the area (Obaje et al., 2004). The Borno Basin is underlain by mostly Precambrian crystalline rocks, which are overlain by sedimentary and volcanic rocks of Cretaceous to Quaternary ages. The sedimentary rocks have a cumulative thickness of about 5 $\mathrm{km}$. They consist of a thick basal continental sequence, overlain by transitional beds, followed by a thick Quaternary limnic fluviatile succession and Aeolian sands and clays (Matheis, 1976; Adegoke et al., 1978; Whiteman, 1982).

The integration of geophysical and other exploration techniques with biostratigraphy, well logs analysis, geochemistry, etc. has contributed enormously to oil and gas exploration all over the world (Payne et al., 1999; Farley \& Armentrout, 2000; Valenti, 2002; Giwa et al., 2005). Biostratigraphy's application to hydrocarbon exploration and production is based mainly on

Research article

Clndian Society for Education and Environment (iSee) foraminifera, palynomorphs, nannofossils, and other microfossil groups.

Compared to other Nigerian basins, Borno Basin's Cretaceous sediments biostratigraphy has not been adequately studied even though few published studies are available (Carter et al., 1963; Adegoke et al., 1978; Poppof et al., 1986; Adegoke et al., 1986; Ola-Buraimo \& Boboye, 2011). Poppof et al. (1986) investigated the Upper Cretaceous Gongilla and Pindiga Formations' ammonite assemblages and recognized seven ammonite zones in the Upper Cenomanian - Lower and Middle Turonian strata. Adegoke et al. (1978) dated the KerriKerri Formation Paleocene on the basis of pollen and spores while Carter et al. (1963) age assignment to KerriKerri Formation was based on Shell-BP Palynologists dating. The coal in the Kerri-Kerri Formation yielded palynomorphs on the basis of which Shell_BP Palynologists dated it Paleocene. Ola-Buraimo and Boboye (2011) also dated the Bima Formation based on the palynomorphs content. Other studies are documented in propriety reports belonging to the various oil companies.

This present study attempts a high-resolution stratigraphic differentiation of the basin's strata penetrated by Kemar-1 well (Fig.1) based on microfloral and microfaunal assemblages. Index fossils useful in delimiting locally defined zones and which provide a means of correlation with adjoining basins were identified 
Fig. 1. Geological Map of Nigeria showing the location of the Nigerian sector of the Chad Basin (Bornu Basin) and Kemar-1 well (Genik, 1993)

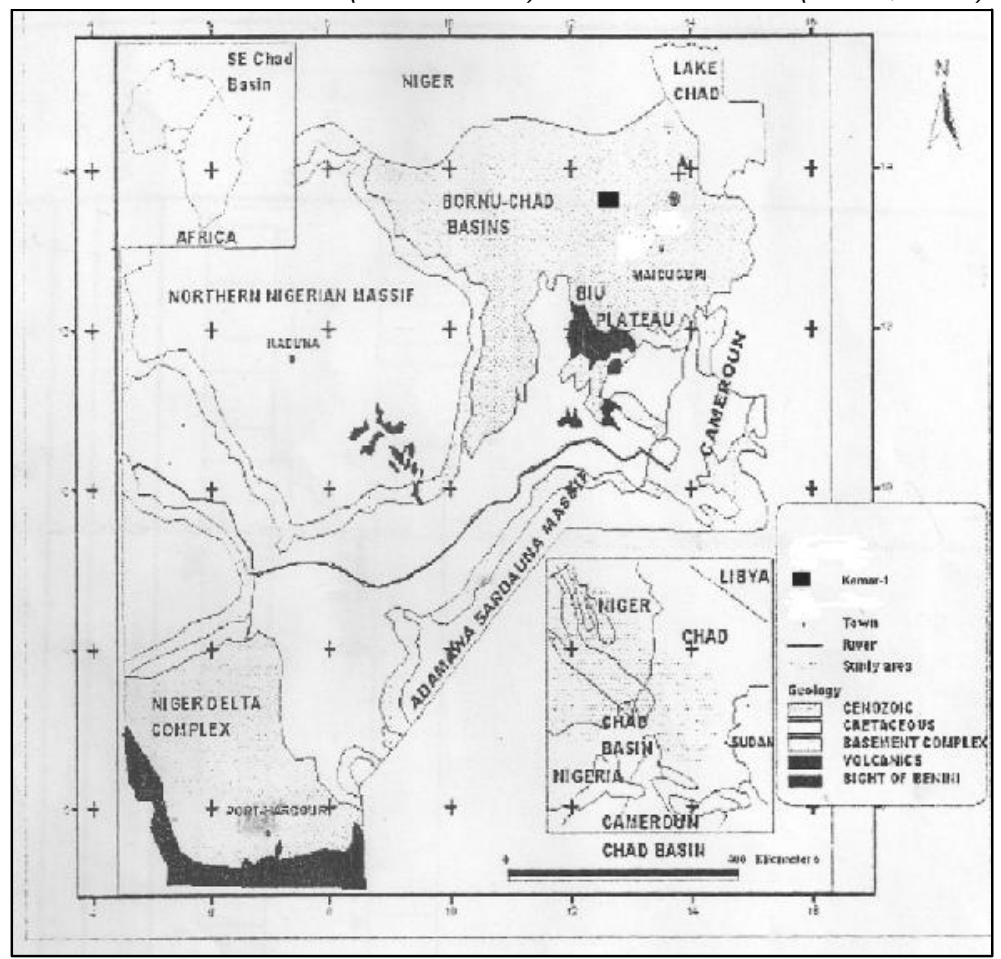

Vol. 5 No. 6 (June 2012)

ISSN: 0974- 6846
Fig.2. Lithostratigraphic succession in Kemar-1

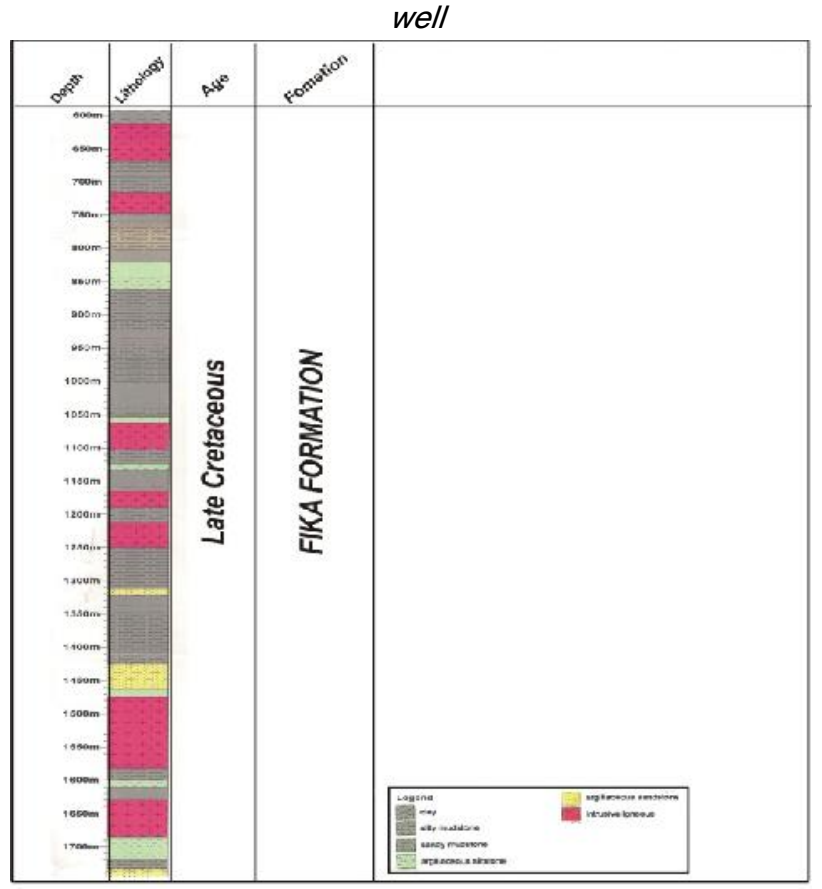

Fika, Gombe, Kerri-Kerri and Chad Formations. Structural features of the basin are mainly products of structural and tectonic events during Late Cretaceous times that shaped the basin. Odusina et al. (1983) pointed out that the geologic evolution of both the Borno Basin and the Upper Benue Trough are related. He identified four main structures, based on seismic line analysis, which are Intrusive features of either igneous or sedimentary origin, Mound structure growth faults and stratigraphic traps, Graben structures and growth faults, and Onlap sequences. Avbovbo et al. (1986) also identified two major structural styles based on seismic line. They are fold-related structures with low fold frequency and fault-related structures. The latter involve the basement and the resulting horsts and grabens with preponderance of high angle normal faults and paucity of reverse faults, indicating dominance of tensional movement.

\section{Materials and methods}

One hundred and eighty one drill cutting samples, provided by the Nigerian Geological Survey Agency (NGSA), selected between 600 and $1745 \mathrm{~m}$ interval of the Kemar-1 well were used for this study.

\section{Lithostratigraphic analysis}

A stereoscopic binocular microscope was used to describe the textural parameters of the samples. The lithofacies are mainly made up of predominantly grey to dark grey shale, sandy mudstone and silty mudstone. An intrusion of igneous lithology within the studied intervals with intercalations of argillaceous sandstone and argillaceous siltstone also occurs. Fig. 2 shows a Lithostratigraphic log for the studied interval. cycle of transgression and regression. It has been divided into six units based on the nature of sedimentary deposits within the depression. The divisions are Bima, Gongila, 
Fig.3. Palynological distribution chart

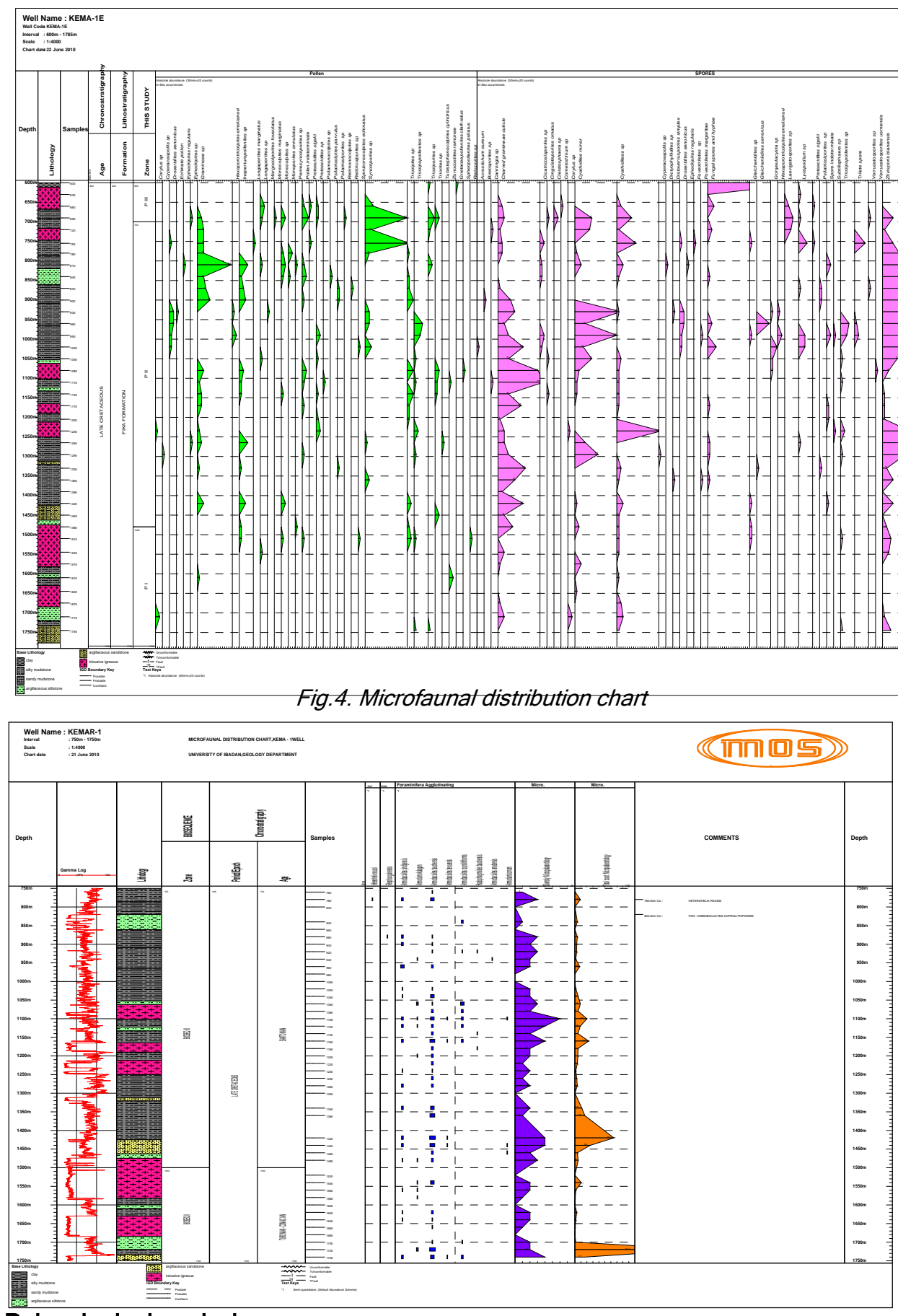

remove the water content and mounted on slides (Traverse, 1988). The palynomorphs were analysed and identified with a high-power microscope. The well yielded a fairly rich and well preserved assemblage of pollen, spores, dinoflagellate cysts and freshwater algae. The identified microfloral taxa are presented in a distribution chart (Fig.3). Palynomorph abundance and species diversity and important biodatums made biozonation possible, while age determinations relied largely on index pollen and spores found.

\section{Foraminiferal analysis}

The studied samples were composited at $20 \mathrm{~m}$ intervals to make the total of 45 samples, which were analyzed for foraminifera. They were soaked with kerosene

Palynological analysis

Thirty-eight ditch cutting samples composited at an interval of $30 \mathrm{~m}$, were analyzed for the palynomorph content, using International Standard for Palynological Analysis procedures (Brown, 1960; Staplin et al., 1960; Faegri et al., 1989; Moore et al., 1991). These consisted essentially of treating the samples with $50 \%$ hydrochloric acid $(\mathrm{HCl})$, concentrated hydrofluoric acid (HF), concentrated nitric acid $\left(\mathrm{HNO}_{3}\right)$ and $5 \%$ potassium hydroxide $(\mathrm{KOH})$. The residues were washed in alcohol to

Research article

CCIndian Society for Education and Environment (iSee)
"Biostratigraphy of Borno basin" http://www.indjst.org and detergent solution, washed and oven-dried. Foraminifera and other accessory microfauna were picked from the washed samples employing a binocular microscope at X140 magnification (Petters, 1982; Fayose, 1970). The foraminifera were identified following classification of Bolli and Saunders (1985) and Leoblich and Tappan (1988). Few but diverse assemblages of planktic and benthic foraminifera were recovered from the samples, which are presented in a microfaunal 
Fig.5. Palynomorphs Zones recognized in Kemar-1 well

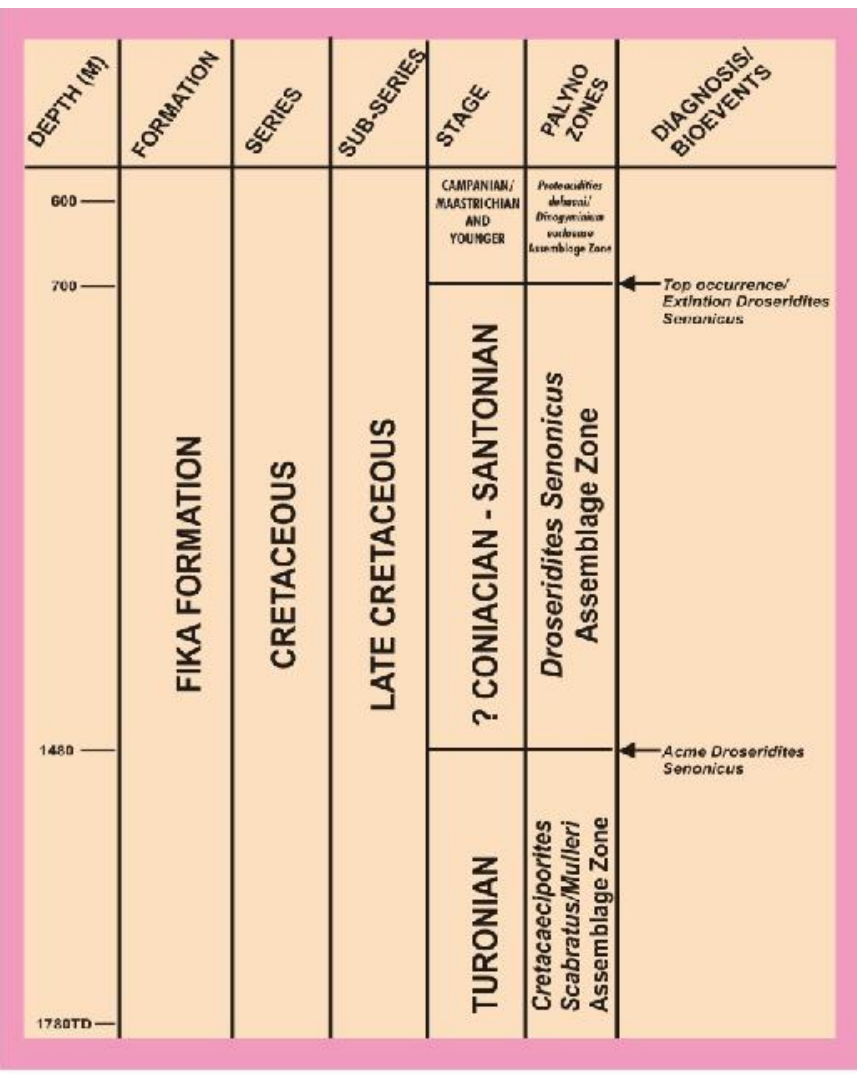

Fig.6.Biosequences recognized in Kemar-1 well

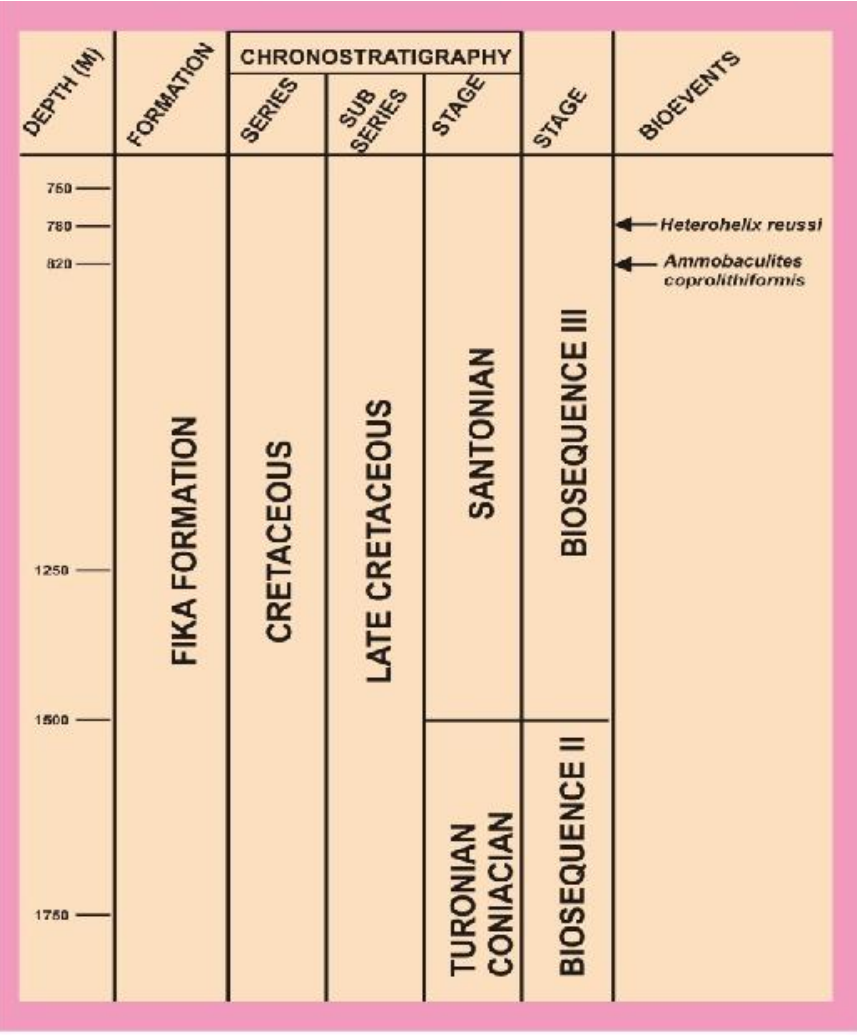

distribution chart (Fig.4). Age and biosequences were then deciphered from the important bio-events.

Results and discussion

The well yielded moderately rich and well preserved pollen, spores, dinoflagellate cysts and freshwater algae assemblages. From these, 89 palynomorphs species were recovered. The microfloral assemblage is dominated by land-derived forms such as Droseridites senonicus, Ephedripites sp., Monocolpites sp., Glecheniidites senonicus, Tricolporopollenites sp., Zlivisporis blanensis and Cyathidites minor. Three Assemblage Zones defined by Jardiné \& Magloire (1965); Jan du Chêne et al. (1978); Müller et al. (1987); Lawal \& Moullade (1986); Salard-Cheboldaeff (1990); Jan du Chêne (2000) were established for the investigated interval based on the first and last appearances of diagnostic marker species. The upper part of the well section correlates with the Proteacidites dehaani/Dinogymnium euclaense Assemblage Zone erected by Lawal and Moullade (1986), followed by Droseridites senonicus Assemblage Zone while the basal sequence correlates with the Cretacaeiporites scabratus/mulleri Assemblage Zone of Müller et al. (1987).

In establishing the foraminiferal biostratigraphy of Kemar-1 well, 45 ditch cutting samples were analysed. They yielded moderately abundant and diversified microfossils throughout the well, which enhanced the zonation. Two biosequences were established for the studied interval (740-1745m) within the well based on the peak and the bioevents. The palynozones and the biosequences recognized are presented graphically in Fig. 5 and 6 respectively and briefly discussed below:

Palynological biozonation of Kemar-1 well

Cretacaeiporites scabratus/mulleri Assemblage Zone (P I)

Stratigraphic Interval: 1480 - 1780m

Formation: Fika Formation

Age: Turonian (90.4Ma)

Description: This is the oldest Assemblage Zone recognized in Kemar-1 well. The top of the Zone is marked by the peak occurrence of Droseridites senonicus at $1480 \mathrm{~m}$ (Lawal and Moullade, 1986). The base of the Zone was not penetrated at the last sample analysed $(1780 \mathrm{~m})$. In this assemblage zone occur Trocolporopollenites sp., Cyathidites minor and Monosulcites sp. Few dinoflagellate cysts e.g., Cleistosphaerium sp., Exochosphaeridium sp., and Subtilisphaera sp. and freshwater algae, Botryococcus braunii were also recorded.

Droseridites senonicus Assemblage Zone (P II)

Stratigraphic Interval: 700 - 1480m

Formation: Fika Formation

Age: (?) Coniacian-Santonian (86.6 - 83.0Ma) 
Description: Droseridites senonicus is a key marker for this Zone because of its abundant and consistent occurrence within, and sudden extinction at the top of the Zone. The upper boundary of the Assemblage Zone is therefore defined by the top occurrence / disappearance of Droseridites senonicus at $700 \mathrm{~m}$, while the lower boundary at $1480 \mathrm{~m}$ is marked by the base acme of the same species (Lawal \& Moullade, 1986). Other markers, particularly the dinoflagellate cyst, Oligosphaeridium pulcherrimum and the pollen Hexaporotricolpites emelianovi whose tops should mark the base of the Santonian were not encountered within the interval. Thus the delineation of the Coniacian/Santonian boundary could not be undertaken. The Santonian period in this well is marked by an abrupt increase in the abundance and diversity of the microflora content. The commonest forms are Monocolpopollenites sphaeroidites, Proteacidites sigalii, Tricolporopollenites sp., Droseridites senonicus, Monosulcites sp., Ephedripites sp., Zlivisporis blanensis, Cyathidites minor, Gleicheniidites senonicus, Distaverrusporites simplex, Foveotriletes margaritae and dinoflagellate cysts such as Cribroperidinium $s p$., Spiniferites ramosus, Cleistosphaeridium sp., Florentinia sp., Subtilissphaera pirnaensis and Gonyaulacysta sp. The peak abundance of Tricolporopollenites sp., Tricolporite sp. and Zlivisporis blanensis were recorded between 800 and $1480 \mathrm{~m}$.

Proteacidites dehaani/Dinogymnium euclaense

Assemblage Zone (P III)

Stratigraphic Interval: 600 - 700m

Formation: Fika Formation

Age: (?) Campanian and younger

Description: This is the youngest palynozone recognized in the well section. The top of the zone was not established at the first sample analysed $(600 \mathrm{~m})$. The base is marked by the top occurrence/extinction of Droseridites senonicus at $700 \mathrm{~m}$. The zonal microflora is numerically poor with very rare marker species. Some of the palynomorphs assemblages recorded in the biozone include Graminidites sp., Monocolpites sp. and Aletesporites sp. The spot occurrences of CampanianMaastrichtian dinoflagellates cysts such as Cyathidites sp., Dinogymnium sp., Chenopodipollis sp., Cyperaceaepollis sp., and the absence of Droseridites senonicus (a typical Coniacian-Santonian marker) suggest that this zone is not older than Campanian.

Foraminiferal Biozonation

Biosequence //

Stratigraphic Interval: 1500 - 1750m

Formation: Fika Formation

Turonian to Coniacian (90.4 - 86.6Ma)

Age:

Description: This Biosequence falls largely within the Coastal Deltaic to Shallow Inner Neritic Fika Formation. Its top is marked at $1500 \mathrm{~m}$, while the base was not encountered at the last sample analysed $(1750 \mathrm{~m})$. The bottom part is fairly rich in foraminifera e.g., Ammobaculites benuensis, A. pindigensis, Ammotium nkalagum, and $A$. bornum.

Biosequence III

Stratigraphic Interval: 750-1500m

Formation: Fika Formation

Age: Santonian (83.0Ma)

Description: The bottom of this Biosequence is fairly rich in foraminifera and is marked at $1500 \mathrm{~m}$. Its top is characterized by sudden occurrence of Heterohelix reussi recorded at $780 \mathrm{~m}$. Another important bioevent recorded is the First Downhole Occurrences (FDO) of Ammobaculites coprolithiformis at $820 \mathrm{~m}$. Some of the dominant foraminifera within this Zone are Heterohelix reussi, Reophax guineana, Ammotium bornum, $A$. nkalagum, Ammobaculites pindigensis, $A$. bauchensis, $A$. amabensis, $A$. coprolithiformis, and Haplophragmoides bauchensis.

Age

On the basis of the foraminiferal and microfloral assemblages, the age of the fossiliferous interval of the studied section of Kemar-1 well ranges from Early Turonian to Santonian.

\section{Unconformities}

Three unconformities were observed within the studied section of Kemar-1 well at $790 \mathrm{~m}, 1300 \mathrm{~m}$ and $1700 \mathrm{~m}$. The unconformities are marked by noticeable faunal discontinuities, associated paleowater depth reduction and abrupt shift in the environment of deposition.

\section{Paleoenvironmental reconstruction}

Paleoenvironmental indicators are marker species which give reliable and accurate information about past environments. When these indicators are efficiently utilized, many of the hindrances encountered in paleoenvironmental synthesis can be avoided. The paleoenvironmental reconstruction of the sequences penetrated by Kemar- 1 well was based on the qualitative evaluation of the bathymetric ranges of carefully chosen environmentally sensitive foraminifera (Adegoke et al., 1976; Murray, 1991; Gebhardt, 1997). These are diverse and well preserved arenaceous foraminifera indicating shallow marine environment and which include Ammobaculites bauchensis, A. coprolithiformis, $A$. pindigensis, $A$. benuensis, Ammotium nkalagum, $A$. bornum and Haplophragmoides bauchensis. According to Gebhardt (1997), the known ecology of Ammobaculites bauchensis, $A$. benuensis, $A$. pindigensis and $A$. coprolithiformis is normal marine to brackish shelf. While Ammobaculites bauchensis, $A$. benuensis and $A$. coprolithiformis can tolerate reduced oxygen contents, Ammobaculites pindigensis on the other hand has very little or no tolerance against oxygen deficiency (Gebhardt, 1998; 2006). Ammobaculites coprolithiformis has also been found to occur in sediments interpreted as marsh and estuarine deposits, probably deeper portions of 
estuaries (Wightman 1990). Haplophragmoides bauchensis is typical of inner shelf and normal marine and tolerates reduced oxygen contents (Gebhardt, 1997). The environment of deposition of the studied section of the well was therefore interpreted to be generally shallow. It ranged from Coastal Deltaic through Fluviomarine to Shallow Inner Neritic (Adegoke et al., 1976). Details of the paleoenvironmental interpretations are presented below:

Interval: 1780-1720 m

Discussion: The interval consists of fairly thick sand/silt beds alternating with delta plain shale. Its fauna consists of few Ammobaculites bauchensis, A. coprolithiformis, and $A$. pindigensis. A single dinoflagellate cyst was recorded along with poor records of land-derived sporomorphs. This signifies a Fluviomarine environment at the lower part deepening to Shallow Inner Neritic towards the upper part.

Interval: 1720-1472 m

Discussion: This interval is predominantly delta plain sand alternating with shallow marine shales. An upward coarsening regressive sand alternating with thin greenish shales occur. Rare Ammobaculites pindigensis, $A$. bauchensis and Ammotium nkalagum were recorded together with pollen and spores such as Cyathidites minor, Zlivisporis blanensis, Glecheniidites spp., Triorites sp., Araucariacites australis, Tricolporopollenites spp., and fairly rich dinoflagellate cyst occurrence. The interval can be interpreted to have been deposited in Coastal Deltaic environment at the lower part, while it varied between Coastal Deltaic and Fluviomarine environments at the upper part.

Interval: 1472-1044 m

Discussion: Marginal marine to Lagoonal shale deposits with prograding interval within the marginal marine environment composed of sand/silt beds alternating with dark grey shales make up this depth interval. Ammotium bornum, Ammobaculites pindigensis, A. coprolithiformis, $A$. bauchensis and $A$. benuensis are common to abundant. Dinoflagellate cysts e.g., Spiniferites ramosus, Dinogymnium euclaense, Leptodinium spp., Cribroperidinium spp., Cleistosphaeridium sp., and Gonyaulacysta sp. are abundant while Botryococcus braunii and Pediastrum sp. are rare. This indicates a Fluviomarine environment with an occasional Shallow Inner Neritic influence at the lower part, while the environment fluctuated between Coastal Deltaic and Fluviomarine with an occasional Shallow Inner Neritic influence at the upper part.

Interval: 1044-910 m

Discussion: The strata are Lower Subaqueous Delta deposits consisting of thin bedded sand/silt horizons alternating with delta plain shale and rare occurrence of Ammobaculites pindigensis, $A$. bauchensis, and $A$. coprolithiformis. The interval yielded abundant landderived sporomorphs dominated by Gleicheniidites senonicus, Cyathidites minor, Zlivisporis blanensis,
Vol. 5 No. 6 (June 2012)

ISSN: 0974- 6846
Tricolpites sp., Tricolporopollenites sp., and Triorites sp. Dinoflagellate cysts and algae also occur fairly abundantly. An environment that varied between Coastal Deltaic and fluviomarine is inferred for the interval.

Interval: 910-762 m

Discussion: Upper Subaqueous Delta deposits with moderately thick sand/silt beds alternating with delta plain shale constitute this interval. Rare Ammobaculites bauchensis, $A$. coprolithiformis, $A$. pindigensis, and Haplophragmoides bauchensis occur. It is typified by abundant sporomorphs occurrence dominated by Tricolporopollenites sp., Cyathidites minor, Zlivisporis blanensis, Gleicheniidites senonicus, Droseridites senonicus, Tricolpites sp., and Rugulatisporites caperatus and fair and poor dinoflagellate cyst and records respectively. A Coastal Deltaic/ Fluviomarine environment is inferred (Frederiksen, 1985).

Interval: 762-668 m

Discussion: This interval consists of floodplain and overbank deposits, which include thin bedded silty sands alternating with shales. It has rare Ammotium nkalagum, Ammobaculites bauchensis, and $A$. benuensis. It has drastically reduced land-derived sporomorphs and dinoflagellate cysts with spot occurrences of fresh water algae. It was deposited in a Coastal Deltaic environment with occasional fluviomarine influence (Adegoke et al., 1976; Murray 1991).

Interval: 668-600 m

Discussion: Alluvial fan to Flood plain deposits make up this interval. Its strata are pebbly, very coarse grained and poorly sorted fanglomerate sandstones. The clay constitutes the flood plain deposits. It is barren of foraminifera except for the lower part that yielded rare Ammobaculites spp., $A$. pindigensis, and Ammotium nkalagum. It also has a very poor record of sporomorphs.

\section{Conclusion}

Biostratigraphy is a valuable tool in oil and gas exploration when it is integrated with other geological and geophysical data sets, such as outcrops, seismic lines or well logs. This paper constitutes a significant contribution to the understanding of the biostratigraphy of Borno Basin, which is currently the focus of intensive hydrocarbon exploration activities. This study has employed microfaunal and microfloral assemblages for the stratigraphic differentiation of the strata penetrated by Kemar-1 well in Borno Basin. Attempts have also been made to date the strata and to deduce their depositional environments. Three palynological zones and two foraminiferal biosequences whose age range between Early Turonian to Early Campanian were established for the studied interval, which is Fika 'Shale' Formation. The environment of deposition is also largely Shallow Inner Neritic. 
Fig. 7. Palynomorphs recognized in Kemar-1 well:

1. Lygodium reticulatiformis Jardiné \& Magloire, 1965

2. Smooth trilete sinuose

3. Zlivisporis blanensis Boltenhagen, 1967

4. Smooth trilete verrucose sp. (spore indeterminate) Lawal, 1982

5. Large smooth trilete

6. Gabonisporis vigourouxi Boltenhagen, 1967

Fig. 7.Palynomorphs recognized in Kemar-1 well
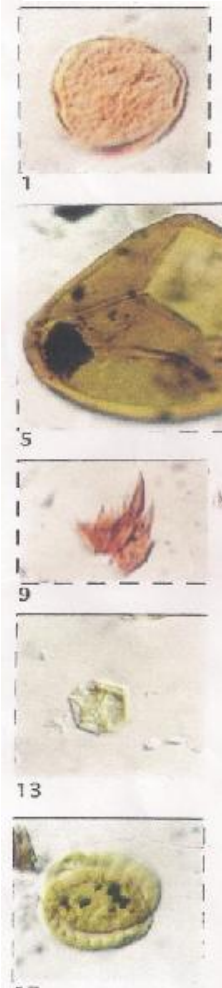

17
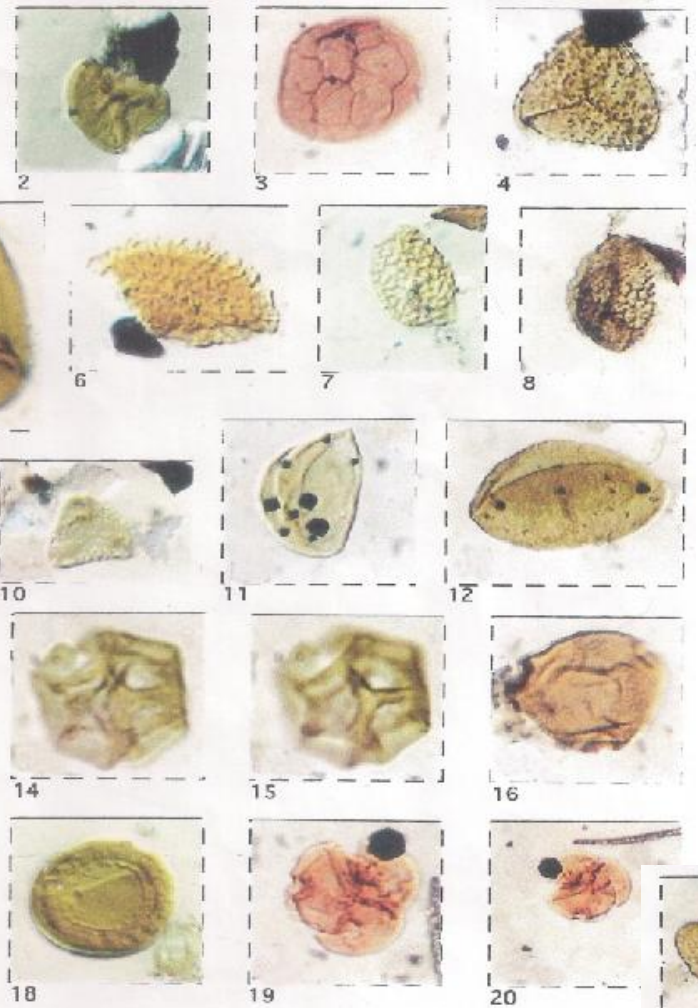

7. Retimonocolpites sp. Lawal, 1982

8. Retimonocolpites sp. Lawal, 1982

9. Scolecodont

10. Tricolpites sp. Jardiné \& Magloire, 1965

11. Longapertites microfoveolatus Adegoke et al., 1978

12. Longapertites chlonovae Boltenhagen, 1978

13. Cretacaeiporites polygonalis Jardiné \& Magloire, 1965 ; Herngreen, 1973

14. Cretacaeiporites polygonalis Jardiné \& Magloire, 1965 ; Herngreen, 1973

15. Cretacaeiporites polygonalis Jardiné \& Magloire, 1965 ; Herngreen, 1973

16. Triporites $\mathrm{sp}$.

17. Tubistephanocolpites cylindricus Salami, 1984

18. Tubistephanocolpites cylindricus Salami, 1984

19. Ericaceae

20. Ericaceae
Fig.8. Palynomorphs recognized in Kemar-1 well:

1. Foveotriletes margaritae (Filtrotriletes nigeriensis) GHM,1968 (Van Hoeken-Klinkenberg, 1964)

2. Cingulatisporites ornatus Van Hoeken-Klinkenberg, 1964

3. Rugulatisporites caperatus Van Hoeken-Klinkenberg, 1964

4. Osmundacidites spp.

5. Droseridites sp. (could be a single grain of a tetrad of Droseridites senonicus)

6. Droseridites sp. (could be a single grain of a tetrad of Droseridites senonicus)

7. Droseridites sp. (could be a single grain of a tetrad of Droseridites senonicus)

8. Droseridites sp. (could be a single grain of a tetrad of Droseridites senonicus)

9. Rhoidipites "scabratus"

10. Rhoidipites "scabratus"

11. Psilatricolporites sp.

12. Psilatricolporites $s p$.

13. Tricolpites sp. Jardiné \& Magloire,1965; Lawal, 1982

14. Tricolpites sp. Herngreen, 1973

15. Tricolpites sp. Herngreen, 1973

16. Syncolporites spp.

17. Syncolporites spp.

18. Syncolporites spp.

19. Tubistephanocolpites cylindricus Salami, 1984

20. Ephedripites zaklinskaiae Azema \& Boltenhagen, 1974

Fig.8. Palynomorphs recognized in Kemar-1 well
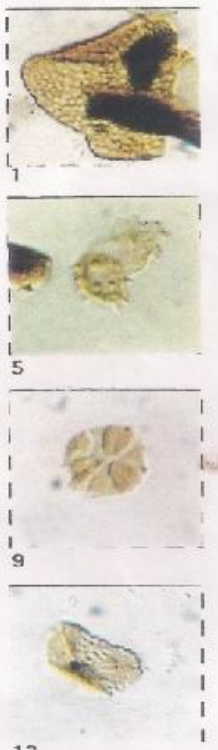

13

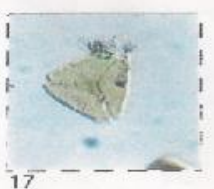

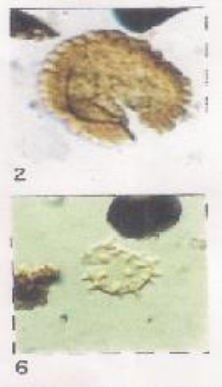

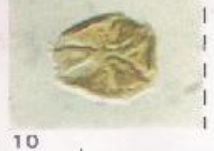

10

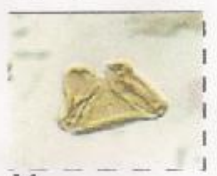

14

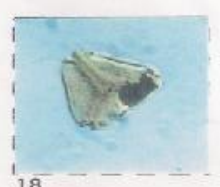

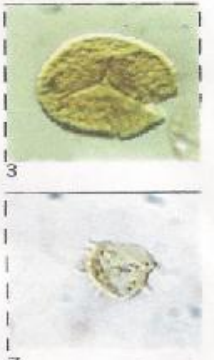

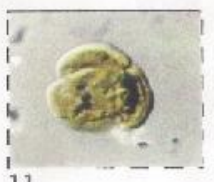

11
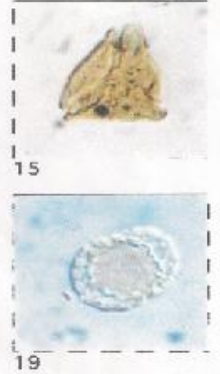

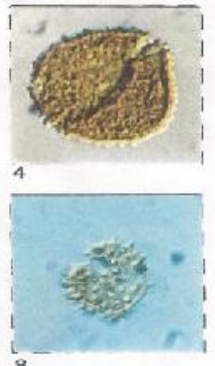

8
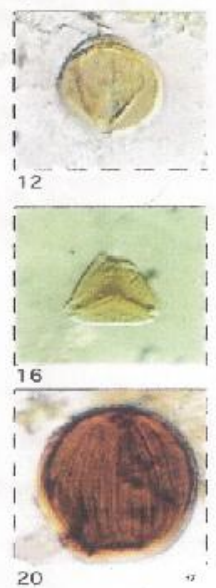

A.K.Adegoke Indian J.Sci.Technol.
Research article

CIndian Society for Education and Environment (iSee)
"Biostratigraphy of Borno basin" http://www.indjst.org 
Fig.9. Palynomorphs recognized in Kemar-1 well:

1. Foveotriletes margaritae (Filtrotriletes nigeriensis) Van Hoeken-Klinkenberg, 1964

Fig. 9. Palynomorphs recognized in Kemar-1 well
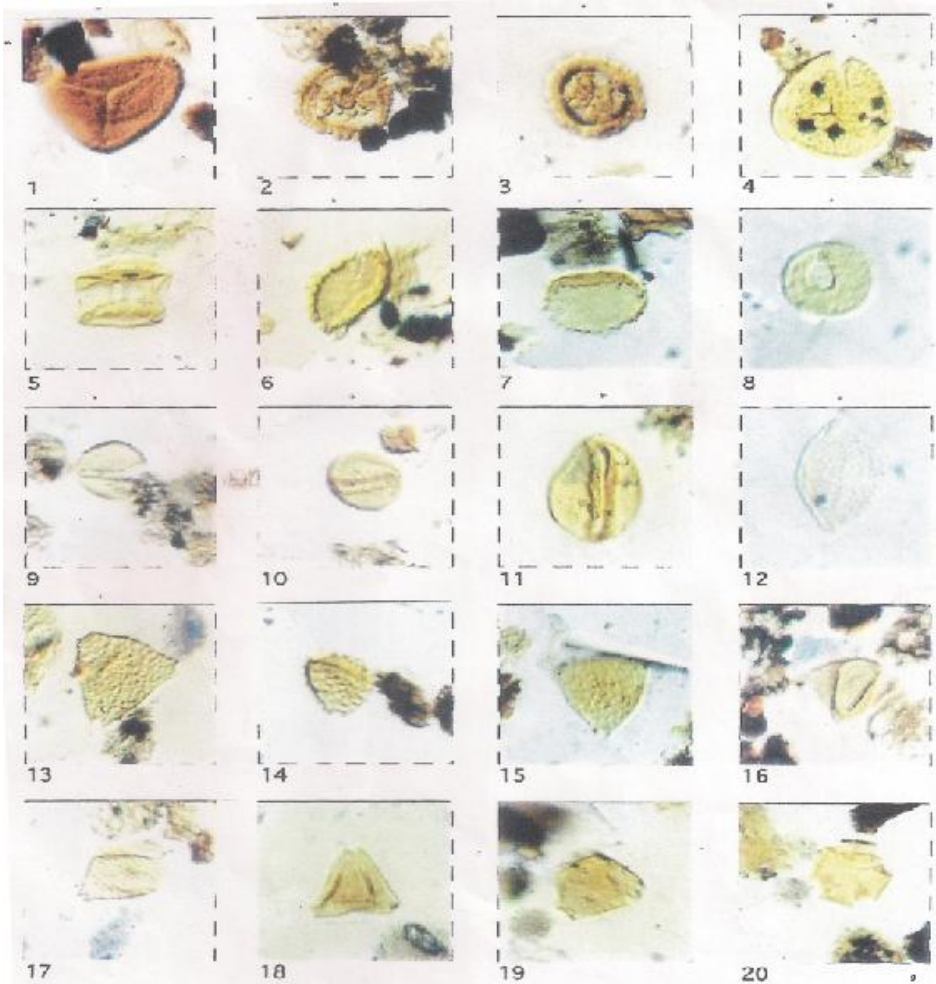

2. Cingulatisporites ornatus Van Hoeken-Klinkenberg, 1964

3. Cingulatisporites ornatus Van Hoeken-Klinkenberg, 1964

4. Lygodium reticulatiformis Jardiné \& Magloire, 1965

5. Tubistephanocolpites cylindricus Salami, 1984

6. Tubistephanocolpites cylindricus Salami, 1984

7. Tubistephanocolpites cylindricus Salami, 1984

8. Graminidites sp. Jardiné \& Magloire, 1965

9. Monocolpopollenites sphaeroidites Jardiné \& Magloire, 1965

10.Monocolpopollenites sphaeroidites Jardiné \& Magloire, 1965

11. Monocolpites marginatus Van der Hammen, 1954

12. Auriculiidites reticulatus Elsik, 1965

13. Proteacidites sigalii Boltenhagen, 1978

14. Echitriporites trianguliformis Van Klinkenberg, 1964

15. Echitriporites trianguliformis Van Klinkenberg, 1964

16. Proteacidites sigalii Boltenhagen, 1978

17. Proteacidites sigalii Boltenhagen, 1978

18. Proteacidites sigalii Boltenhagen, 1978

19. Proteacidites sigalii Boltenhagen, 1978

20. Proteacidites sigalii Boltenhagen, 1978

Hoeken-
Vol. 5 No. 6 (June 2012)

ISSN: 0974- 6846

Fig. 10. Some of the foraminifera recognised in Kemar-1 well:

1. Ammobaculites benuensis Petters, 1979

2. Ammobaculites benuensis Petter, 1979

3. Haplophragmoides bauchensis Petters, 1979

4. Haplophragmoides bauchensis Petters, 1979

5. Ammobaculites coprolithiformis Schwager, 1887

6. Ammobaculites sp. Petters, 1979

Fig. 10. Some of the foraminifera recognised in Kemar-1 well

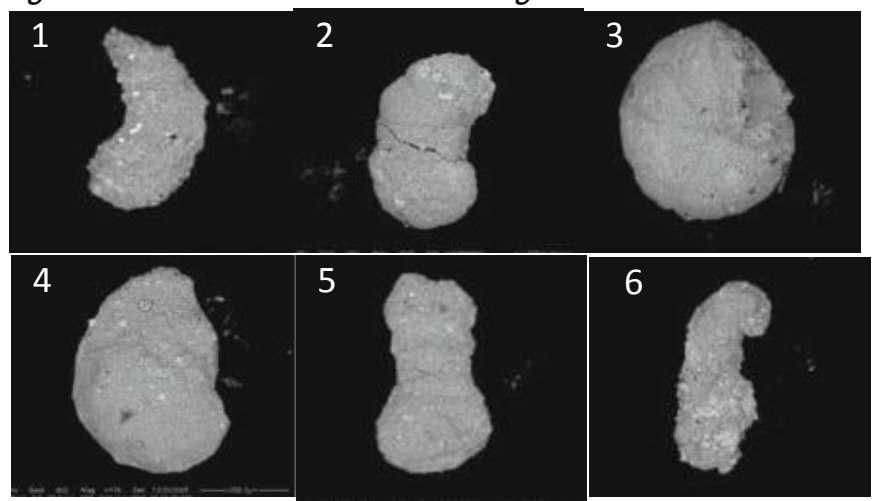

Acknowledgements

The Nigerian Geological Survey Agency (NGSA) is thanked for providing the samples used in this study. The constructive comments of the reviewers are also gratefully acknowledged.

References

1. Adegoke OS, Agumanu AE, Benkhelil MJ and Ajayi PO (1986) New stratigraphic, sedimentologic and structural data on the Kerri-Kerri Formation, Bauchi and Borno States, Nigeria. J. Afr. Earth Sci. 5 (3), 249-277.

2. Adegoke OS, Jan du Chene RE, Agumanu EA and Ajayi PO (1978) Palynology and age of Kerri-Kerri Formation, Nigeria. Revista Espanola Micropal. 10 (2), 267-283.

3. Adegoke OS, Omatsola ME and Salami MB (1976) Benthic foraminiferal biofacies off the Niger Delta. First Int. Symp. on benthic foraminifera of continental margins. Marine Sediments Special Publ. 1, 279-292.

4. Avbovbo AA (1980) Basement geology in the sedimentary basins of Nigeria. Geology. 8, 323 - 327.

5. Avbovbo AA, Ayoola EO and Osahon GA (1986) Depositional and structural styles in Chad Basin Northeastern Nigeria. AAPG Bull. 70, 1787-1798.

Hoeken- 6. Azema C and Boltenhagen E (1974) Pollen du Cretácé Moyen du Gabon attribué aux Ephedrales. Paléobiologie Continentale. 5, 1-37.

7. Bolli HM and Saunders JB (1985) Oligocene to Holocene low latitude planktic foraminifera. In: Bolli HM, Saunders JB and Perch-Nielsen K, Eds., Plankton Stratigraphy. Cambridge University Press, Cambridge. pp: 55-262.

8. Boltenhagen E (1967) Spores et pollen du Cretace superieur du Gabon. Pollen et Spores. 9, 335-355.
Research article

CCIndian Society for Education and Environment (iSee)
"Biostratigraphy of Borno basin" http://www.indjst.org
A.K.Adegoke Indian J.Sci.Technol. 
9. Boltenhagen E (1978) Proteacidites sigalii, espèce nouvelle de pollen proteaceoide du senonien du Gabon. Revista Española Micropal. 21(4), 13-15.

10. Brown CA (1960) Palynological techniques. Louisiana State University Press, Baton Rouge, Louisiana. pp:188.

11. Burke K, Dessauvagie TFJ and Whiteman AJ (1972) Geological history of the Benue valley and adjacent areas. In: African Geology. Dessauvagie TFJ \& Whiteman AJ (Eds.), University of Ibadan Press, Ibadan, Nigeria. pp:187 - 205.

12. Carter JD, Barber W and Jones GP (1963) The geology of parts of Adamawa, Bauchi and Bornu provinces in northeastern Nigeria. Bull. Geol. Surv. Nigeria. 30. 109.

13. Faegri $\mathrm{K}$, Iversen $\mathrm{J}$, Kaland $\mathrm{PE}$ and Krzywinki $\mathrm{K}$ (1989) Textbook of pollen analysis ( $4^{\text {th }}$ Ed.), Wiley, Chichester.

14. Fairhead JD (1986) Geophysical controls on sedimentation with the African Rift Systems. In: Sedimentation in the African Rifts. Frostick LE et al., (Eds.). Geol. Soc. Spec. Publ. 25, 19-27.

15. Fairhead JD and Binks RM (1991) Differential opening of the Central and South Atlantic Oceans and opening of the West African Rift System. Tectonophysics. 187, 191-203.

16. Farley MB and Armentrout JM (2000) Fossil in the oil patch. Geotimes (Newsmagazine of the Earth Sciences), American Geological Institute, Alexandria, VA, USA.

17. Fayose EA (1970) Stratigraphic paleontology of Afowo-1 well, SW Nigeria. J. Min. Geol. Nig. 5(1), 23-34.

18. Frederiksen NO (1985) Review of early Tertiary sporomorph paleoecology. Am. Asso. of Stratigraphic Palynologists Foundation, Dallax, Texas, USA. pp: 92.

19. Gebhardt H (1997) Cenomanian to Turonian foraminifera from Ashaka (NE Nigeria): Quantitative analysis and palaeoenvironmental interpretation. Cretaceous Res. 18, 17-36.

20. Gebhardt H (1998) Benthic foraminifera from the Maastrichtian lower Mamu Formation near Leru (southern Nigeria): Paleoecology and paleogeographic significance. J.Foraminiferal Res. 28, 76-89.

21. Gebhardt $H$ (2006) Resolving the calibration problem in Cretaceous benthic foraminifera paleoecological interpretation: Cenomanian to Coniacian assemblages from the Benue Trough analyzed by conventional methods and correspondence analysis. Micropaleontol. 52 (2), 151-176.

22. Genik GJ (1992) Regional framework, structural and petroleum aspects of rift basins in Niger, Chad and the Central African Republic (C.A.R.). Tectonophys. 213, 169-185.
23. Giwa GO, Oyede AC and Okosun EA (2005) Advances in the application of biostratigraphy to petroleum exploration and production. Abstract, AAPG Intl. Conf., Paris, France.

24. Herngreen GFW (1973) Palynology of AlbianCenomanian strata of Borehole QS. 1MA, strata of Maranhao, Brazil. Pollen et Spores. XV, 34, 515 555.

25. Jan du Chene RE (2000) Palynological study of the Lower Cretaceous section from the Well Ise-2, Nigeria. Geological Implications for the deep offshore interpretation of the Basin Embayment. Afr. Geosc. Rev. 7(1), 1-17.

26. Jan du Chene RE, De Klasz I and Achibong EE (1978) Biostratigraphic study of the borehole Ojo-1, S.W. Nigeria, with special emphasis on the Cretaceous microflora. Rev. Micropaleont. 21(3), 123-139.

27. Jardine S and Magloire L (1965) Palynologie et stratigraphie du Crétacé des basins du Senegal et de Côte d' Ivoire. Ler Coll. African Micropali., Dakar, Mem. Bur. Rech. Géol. Min. 32, 187-245.

28. Lawal O (1982) Biostratigraphic palynologique et paleoenvironment des Formations Cretaceous de in Haute Benue, Nigeria Mid-Oriculal. These 3' cycle Univ. Nice, Géologie et Minière, 198.

29. Lawal $O$ and Moullade M (1986) Palynological biostratigraphy of Cretaceous sediments in the upper Benue Basin, N.E. Nigeria. Rev. Micropaleont. 29 (1), 61-83.

30. Loeblich AR Jr. and Tappan H (1988) Foraminiferal genera and their classification. Van Nostrand Reinhold, NY,

31. Matheis G (1976) Short review of the geology of the Chad Basin in N.E. Nigeria. In: Geology of Nigeria. Kogbe CA (ed.), Elizabethan Publ. Co., Lagos, Nig. pp: 289-294.

32. Moore PD, Webb JA and Collinson ME (1991) Pollen analysis $\left(2^{\text {nd }}\right.$ Edition). Blackwell Scientific Publ., Oxford, UK.

33. Müller J, Di Giacomo E and Van Erve A (1987) A palynologic zonation for the Cretaceous, Tertiary and Quaternary of Northern South America. Am. Asso. of Stratigraphic Palynologists Contribution Series. 19, 776.

34. Murray JW (1991) Ecology and paleoecology of benthonic foraminifera. Longman Scientific \& Technical Publ., NY. pp: 397.

35. Obaje NG, Wehner H, Scheeder G, Abubakar MB and Jauro A (2004) Hydrocarbon prospectivity of Nigeria's inland basins: From the viewpoint of organic geochemistry and organic petrology. AAPG Bull. 88(3), 325-353.

36. Odusina AA, Mubarak SO, Beka FR and Nwangwu $U$ (1983) Geology and petroleum potential of the Nigerian sector of Chad Basin. Res. Bull. Vol. III, Exploration Research \& Services Department (R\&D),
Research article

(C)Indian Society for Education and Environment (iSee)
"Biostratigraphy of Borno basin" http://www.indjst.org
A.K.Adegoke Indian J.Sci.Technol. 
Project no: ER/RD/42, NNPC, Port Harcourt, Nigeria. pp: 47.

37. Okosun EA (1992) Cretaceous ostracod biostratigraphy from the Chad Basin in Nigeria. Jour. Afr. Earth Sci. 14(3), 327-339.

38. Okosun EA (1995) Review of the geology of Bornu Basin. J. Min. and Geol. 31(2), 113-122.

39. Ola-Buraimo OA and Boboye OA (2011) Palynological investigation of the Albian to Lower Cenomanian Bima Formation, Bornu Basin, Nigeria. World Appl. Sci.J. 12(7), 1026-1033.

40. Olade MA (1975) Evolution of Nigeria's Benue Trough (Aulacogen): A tectonic model. Geological Magazine. 112 (6), 575-583.

41. Payne SNJ, Ewen DF and Bowman MJ (1999) The role and value of 'high-impact biostratigraphy' in reservoir appraisal and development. In: Biostratigraphy in production and development geology. Jones RW \& Simmons MD (eds.), Geological Soc. Spl. Publ. 152, 5-22.

42. Petters SW (1979) Paralic arenaceous foraminifera from the Upper Cretaceous of the Benue Trough, Nigeria. Acta Palaeontologica Polonica. 24, 451-471.

43. Petters SW (1981) Stratigraphy of chad and lullemmeden basins (West Africa). Eclogae geol. Helvetiae. 74(1), 139-159.

44. Petters SW (1982) Central West African cretaceoustertiary benthic foraminifera and stratigraphy. Palaeontographica Abt. A. 179, 1-104.

45. Poppof M (1986) The upper cretaceous gongilla and pindiga formations, Northern Nigeria subdivision: Age, stratigraphic correlation and paleographic implication. Eclogae Geol. Helv. Besel. 79, 263-343.

46. Salami MB (1984) Late cretaceous and early tertiary palynofacies of southwestern Nigeria. Revista Española Micropal. 16(1/3), 415-423.

47. Salard-Cheboldaeff M (1990) Intertropical African palynostratigraphy from Cretaceous to Late Quaternary times. J. Afr. Earth Sci. 11, 1-24.

48. Staplin FL, Pocock SJ, Jansonius J and Oliphant EM (1960) Palynological techniques for sediments. Micropaleontol. 6, 329-331.

49. Traverse A (1988) Paleopalynology. Allen and Unwin Inc., USA. pp: 600.

50. Valenti R (2002) High-impact palynology in petroleum geology: Applications from Venezuela (northern South America). AAPG Bull. 86, 279-300.

51. Van der Hammen T (1954) The development of Colombian flora throughout geologic periods. I. Maastrichtian to Lower Tertiary. Boletín Geológico (Bogotá). 2, 49-106.

52. Van Hoeken-Klinkenberg, PMJ (1964) A palynological investigation of some Upper Cretaceous sediments in Nigeria. Pollen \& Spores. 6(1), 209-231.
53. Whiteman AJ (1982) Nigeria: Its petroleum geology, resources and potential. Graham \& Trotman Publ., London, UK. Vols. 1 and 2, pp: 394.

54. Wightman WG (1990) Estuarine and marsh foraminifera from the Lower Creataceous of the Lusitanian Basin, West Portugal. In: Paleoecology, biostratigraphy, paleoceanography and taxonomy of agglutinated foraminifera. Hemleben $C$, Kaminski MA, Kuhnt W, Scott DB (Eds.) NATO ASI-Series C 327. Dordrecht: Kluwer Academic Publ. pp: 739-764.

55. Wright JB (1968) South Atlantic continental drift and Benue Trough. Tectonophysics. 6(4), 301-310. 